\title{
悪性脳腫瘍に対する光線力学的療法（PDT）の基礎
}

\author{
山本 哲哉, 上月 暎浩, 鶴淵 隆夫, 松田 真秀, 阿久津 博義, 石川 栄一, 高野 晋吾, \\ 松村 明 \\ 筑波大学医学医療系脳神経外科
}

\section{Basics of Photodynamic Therapy for Malignant Brain Tumors}

\author{
Tetsuya Yamamoto, M.D., Ph.D., Hidehiro Kozuki, M.D., Takao Tsurubuchi, M.D., Ph.D., \\ Masahide Matsuda, M.D., Ph.D., Hiroyoshi Akutsu, M.D., Ph.D., Eiichi Ishikawa, M.D., Ph.D., \\ Shingo Takano, M.D., Ph.D., and Akira Matsumura, M.D., Ph.D.
}

Department of Neurosurgery, Faculty of Medicine, University of Tsukuba

Photodynamic therapy (PDT) for primary malignant brain tumors has now been approved for coverage under Japanese national health insurance. In this therapy, talaporfin sodium (Laserphyrin ${ }^{\circledR}$ ) is used as a photosensitizer to be used along with an exclusively developed laser beam source. PDT is a tumor-selective, bimodal treatment, that is based on various photodynamic reactions involving molecular oxygen and oxygenated products, which are harmful for tumor tissue. After administration, the photosensitizer is accumulated and localized in the tumor tissue, which is then exposed to a laser beam with a wavelength appropriate for absorption by the sensitizer, providing photodynamic reactions. The treatment rationale, characteristics of talaporfin sodium and the laser source used for PDT of malignant brain tumors are also described.

(Received July 7, 2016 ; accepted August 25, 2016)

Key words : PDT, glioma, talaporfin

Jpn J Neurosurg (Tokyo) $25: 905-911,2016$

\section{はじめに}

原発悪性脳腫瘍に対するタラポルフィンナトリウム (レザフィリン®) を用いた光線力学的治療 (photodynamic therapy：PDT）が 2015 年 5 月に保険収載された。近年 の外科的摘出では, 術中電気生理モニタリングや覚醒下 手術による神経機能の情報, ナビゲーションや術中 MRI，拡散テンソル画像や methionine-PET 等の画像情 報，5-アミノレブリン酸による術中蛍光所見を組み合わ せて, 安全でかつ最大限の摘出が行われている ${ }^{912)}$. 原 発悪性脳腫瘍の代表格である悪性神経膠腫の標準治療は
手術による最大摘出の後にテモゾロミドを併用した X 線 分割照射を行うものである ${ }^{13)}$. このような総合的なアプ ローチによる現在の手術治療によっても，摘出腔周囲に ある肉眼的に識別不能の浸潤腫瘍細胞や，機能局在部位 に近接し意図的に摘出を避けざるを得ない残存腫瘍塊の 発生は避けられず，本腫瘍の再発は発育形態の特徴であ る浸潤性性格や放射線化学療法への抵抗性とも関係し, 全体の $95 \%$ が摘出腔に近接 $(2 \mathrm{~cm}>)$ した脳組織から起

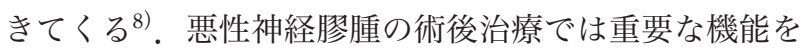
有する脳領域に接した残存腫瘍や，正常脳に浸潤した腫 瘍細胞を完全に治療しても正常脳機能を損なわない，強 
力でかつ腫瘍選択性の高い治療法の開発がこれまでも必 要とされてきた. PDTはこういった難題を解決し得る魅 力的な理論的背景をもつ方法である.

村垣ら ${ }^{6)}$ は, 13 例の初発膠芽腫を含む 27 例の脳腫瘍に 対してのPDTの第 II 相試験を報告し,この臨床試験が保 険適応認可の基礎データとなっている。このPDTの臨床 試験では腫瘍摘出を行った後に, 沉用の手術用顕微鏡に 付設された半導体レーザー照射装置により $15 \mathrm{~mm}$ 径の 円形照射野 1 3 カ所に対してレーザー光 $\left(150 \mathrm{~mW} / \mathrm{cm}^{2}\right.$, $\left.27 \mathrm{~J} / \mathrm{cm}^{2}\right)$ を術中照射している. 光増感剤として用いら れたタラポルフィンナトリウム $\left(40 \mathrm{mg} / \mathrm{m}^{2}\right.$, 静脈内投与 $)$ は，PDT 手技を行う 22〜27 時間前に投与された。軽度 かつ低頻度 $(7.4 \%)$ の皮膚障害を除き重篤な合併症はな く, また 1 年生存率 $100 \%$, 生存期間および無増悪生存 期間はそれぞれ中央值 24.8 力月, 12.0 力月と本治療法の 安全性と効果が示された. PDTの施行に際しては, 外科 的摘出をはじめ, 適応とレーザー照射範囲の判断, 実際 の治療手技，治療後の管理は原則としてすべて脳神経外 科医が行う。本稿では, PDTを行ううえで知っておくべ き基礎的事項の中で, 光増感剤夕ラポルフィンナトリウ ムや励起用レーザーの特性, 抗腫瘍効果等について概説 する。

\section{一重項酸素と光増感剤の働き}

PDT は, 光増感剤の腫瘍集積性と励起用レーザー照射 後の光化学反応を利用し, 腫瘍細胞選択的な効果を得よ うとする手法である.PDTではレーザー光が直接腫瘍組 織に作用するのではなく, レーザー光と光増感剤の反応 を介して腫瘍組織内で発生する一重項酸素が腫瘍細胞に 効果を及ぼす。またその抗腫瘍効果にはアポトーシスや ネクローシス, 腫瘍血管閉塞による腫瘍壊死, さらにサ イトカインを介した機序が関係するとされてい

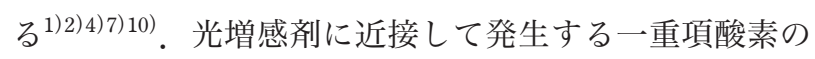
移動距離は $0.1 \mu \mathrm{m}$ 程度 $(0.02 \sim 1)$, その寿命はマイクロ 秒（0.04〜4）オーダーといわれており，光増感剤の腫瘍 集積特性と発生する一重項酸素が光増感剤の腫瘍組織内 分布に一致して殺細胞効果を示すことが, PDT における 腫瘍選択性効果の理論的背景となっている ${ }^{2)}$.

PDT における光増感剤の働きは, 腫瘍組織内の溶存酸 素内に殺細胞効果を有する一重項酸素を効率よく発生さ せることにある。腫瘍組織内での一重項酸素の発生は, 通常の条件下では定状状態にある酸素 (三重項酸素) に 単純にエネルギーを与えて励起させようとしても達成で きない. しかし, 特定波長のレーザー光で励起される光
増感剤の三重項状態は，一重項酸素と三重項酸素との工 ネルギー差にほぼ等しい励起エネルギーを持っていて, 励起された光増感剤が三重項酸素と衝突する際に電子と エネルギーの交換が起こり, 光増感剤が基底状態に戻る と同時に三重項酸素は一重項酸素に容易に遷移する (Type 2 反応)。このような励起方法は光増感法と呼ば れ, PDT では光増感剤による効率的な一重項酸素の発生 が利用されている。したがって, PDTでの光増感剤の役 割は腫瘍組織選択的な分布・集積と光化学反応でのエネ ルギー交換の仲介（光増感剂）が重要である。臨床で用 いられる光増感剤には夕ラポルフィンのほかに先行して 研究されてきた porfimer sodium, aminolevulinic acid hydrochloride, temoporfin などがあるが，国内で使用で き，悪性脳腫瘍に適応があるのは夕ラポルフィンのみで ある。原発悪性脳腫瘍に対する実臨床の PDTでは, まず 患者に薬剂を投与し $\left(40 \mathrm{mg} / \mathrm{m}^{2}\right.$ i. v. $) ， 22 \sim 32$ 時間後に 腫瘍摘出腔の壁や残存腫瘍に対しレーザー光を照射する 方法がとられている。

\section{光増感剤に求められる特性と タラポルフィンナトリウム}

悪性脳腫瘍の PDTに用いる光増感剂は, (1)高い腫瘍細 胞選択性, (2)血液脳関門を通過しない, (3)近赤外線波長 域の $700 \mathrm{~nm}$ 近傍またはより長波長域での吸光特性, (4) 高い光増感作用, (5)低い毒性といった特性が求められ る. PDTの効果はこれらの光増感剤の特性のほかにも, レーザー光の分布強度, 腫瘍組織（細胞）の PDT に対す る感受性，溶存酸素の状態などにも影響を受けると考元 られる. in vitroの細胞照射実験では薬剂濃度依存性の効

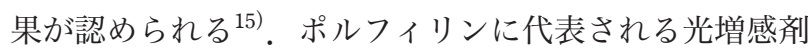
を静脈内投与すると，血液中や細網内皮系や腎排泄系を 除く正常組織では時間経過とともに薬剤濃度が低下する のに対し, 腫瘍内濃度は first pass での低下の後に薬剤濃 度が増加する 2 相性の変化を示す ${ }^{17)}$ 。これは腫瘍親和性 を示すポルフィリン化合物によくみられ，薬剤の両親媒 性, 腫瘍組織での血管透過性元進, LDL やトランスフェ リン，アルブミンへの親和性とレセプター活性の上昇, 細胞内への能動的な取り込み, リンパ系組織の未発達・ 欠如によるがん組織での排泄機能低下に関係して, 緩徐 に腫瘍内濃度が上昇するためと考えられている ${ }^{11)}$.

PDT で高い効果を得るには高い腫瘍内濃度と選択性 が重要である。脳腫瘍組織は壊死部分や細胞密度, 血管 密度が均一ではなく, in vivo のラット脳腫瘍モデルで は, タラポルフィンの壊死部分や浮腫領域への移行は腫 

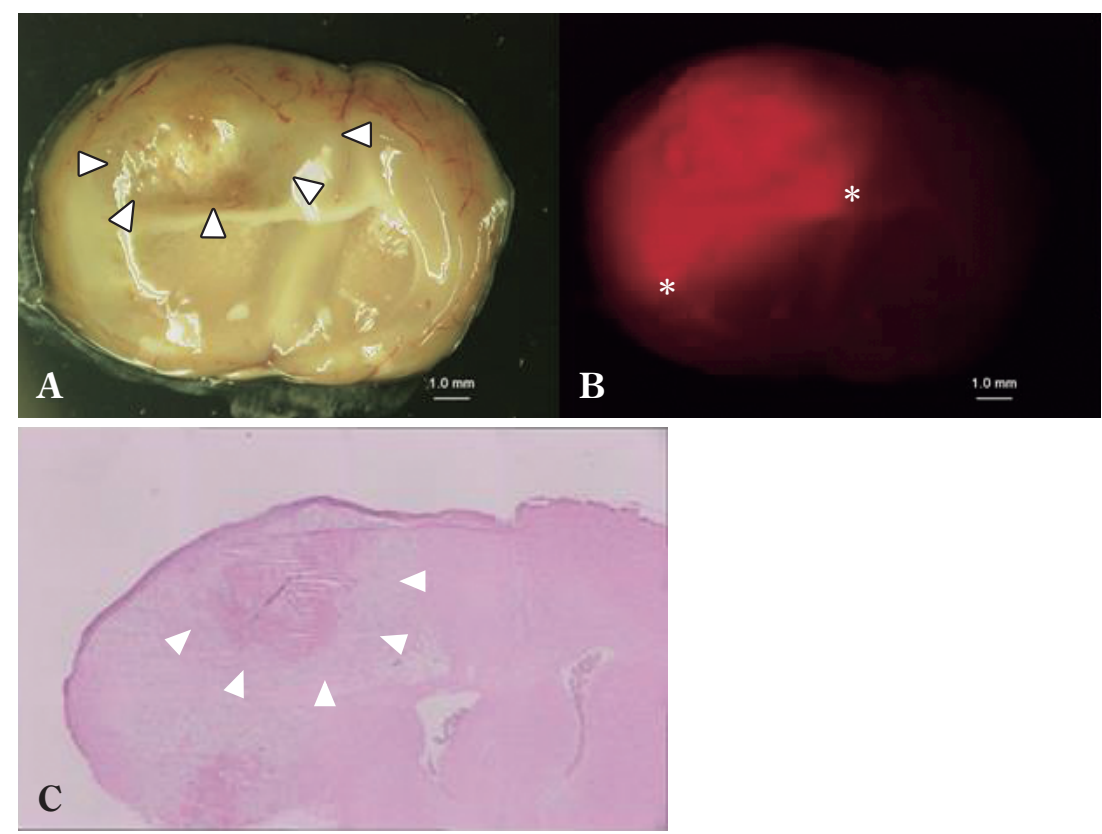

Fig. 1 Photographs showing the macroscopic coronal section (A) and the fluorescence image (B) of a rat $\mathrm{C} 6$ brain tumor model 6 hours after the administration of talaporfin sodium. Arrowheads indicate the tumor margin corresponding to that of the hematoxylin-eosin $(\mathrm{HE})$ staining (C). Fluorescence image was obtained using a $610 \mathrm{~nm}$ long path filter. Asterisks show positive fluorescence in the edematous tissue around the tumor.

瘍組織よりも低いことが示されている゙3. 浮腫領域への 薬剂移行は浸潤腫瘍細胞への治療効果を得るのに有用な 反面，正常組織障害発生の原因となる。脳腫瘍モデルに タラポルフィンを投与し,レーザー光による励起 (670土 $10 \mathrm{~nm})$ を行うと, 腫瘍に一致した明るい赤色蛍光が観察 される $(\text { Fig. 1, 3 })^{14)}$. タラポルフィンは腫瘍に良好に移 行するとともに，腫瘍の範囲から連続して同側の脳組織 にも拡散し，別の凍結損傷血管浮腫モデルでは血液中の タラポルフィン濃度上昇に伴いより早期に腫瘍同様に薬 剤の分布を示す弱い蛍光が観察される (Fig. 2，4)。した がって, 実際の治療においては腫瘍周囲浮腫組織への薬 剂移行を考慮して治療を行う必要がある。

\section{PDT に使用するレーザー}

PDT の光増感では, 病巣に対して正確にかつ十分な照 射量を確保する目的で, 径の細い光源から単一波長で効 率よく照射できるレーザー光が用いられる，悪性脳腫瘍 に対するPDTでは, 手術用顕微鏡に設置したレーザー光 源を使用し, 腫瘍摘出後にその摘出腔内から腫瘍床に向 けてレーザー照射を行う。レーザーの組織透過性には限
界があるので, 腫瘍摘出度は高いほど PDTには有利であ る。また, PDTの腫瘍選択性は光増感剂の腫瘍への親和 性（生物学的選択性）によって得られるが，治療効果は レーザー照射された部分に限って惹起されるので，レー ザーの照射範囲によっても治療範囲を限定することがで きる (物理的選択性).PDT で用いる光増感剤の吸光度 特性は，励起光として用いるレーザーの波長が長いほど 組織深部への到達がよいため, 治療可能な深度と効果に 影響する，光増感剤の吸光度特性は，用いるレーザーの 影響が PDT の照射野（術野）に存在する腫瘍以外の組織 や血液にも影響する。酸化へモグロビンの吸光曲線は $400 \mathrm{~nm}$ と $600 \mathrm{~nm}$ 付近にピークを有し，水では $700 \mathrm{~nm}$ 付 近から急峻に立ち上がることから，両者の吸光度の谷間 にあたる $664 \mathrm{~nm}$ 付近にピークを有し，かつより長波長 を用いることで深部到達性の面で有利なタラポルフィン ナトリウムの吸光度特性はPDTを行ううえで理想的と いえる (Fig. 5)。悪性脳腫瘍に対する PDT の臨床におい ては, 励起光源として励起波長 $664+2 \mathrm{~nm}$ の PDT 半導 体レーザー（PD レーザ BT ZH-LD31A02J，パナソニッ クヘルスケア）が使用されている（Fig. 6)。628〜 635 nm に吸収帯をもつ hematoporphyrin derivative（HPD）では 

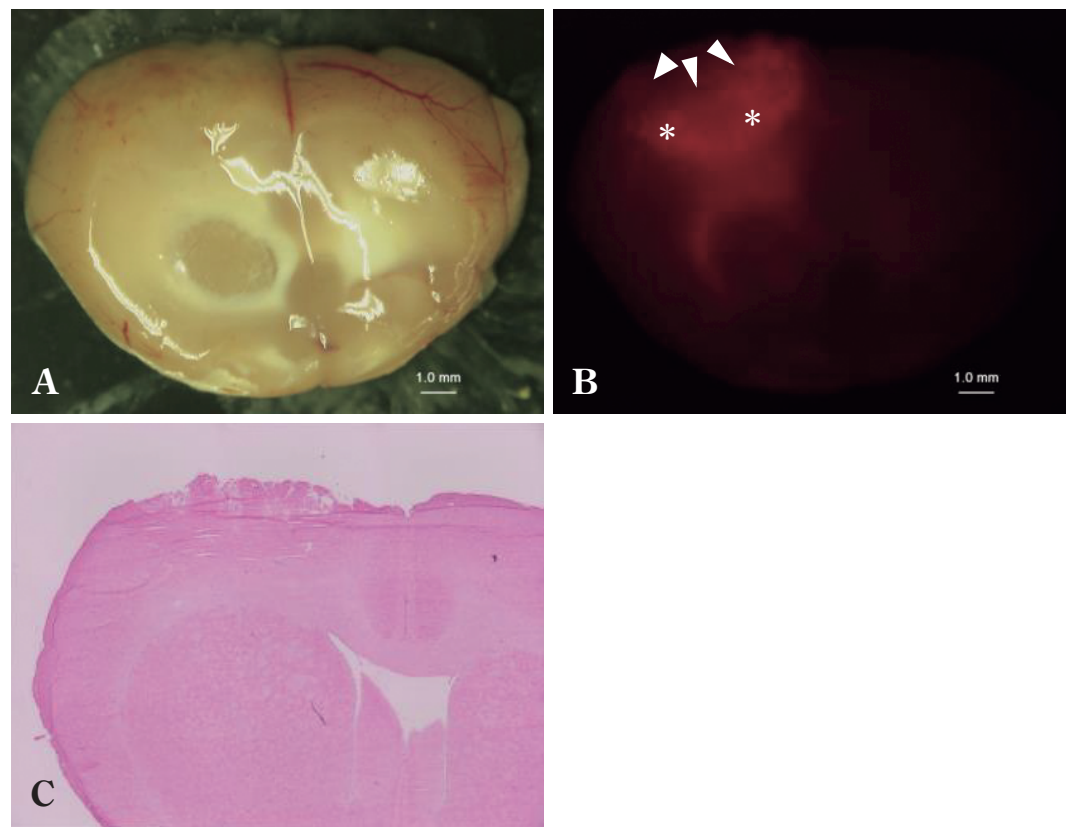

Fig. 2 Photographs showing the macroscopic coronal section (A) and the fluorescence image $(\mathbf{B})$ of a rat cold-injury-induced vasogenic brain edema model 6 hours after the administration of talaporfin sodium. Arrowheads indicate the margin of the cold injury corresponding to that of the hematoxylin-eosin ( $\mathrm{HE}$ ) staining (C). Asterisks show positive fluorescence in the edematous tissue around the cold injury.

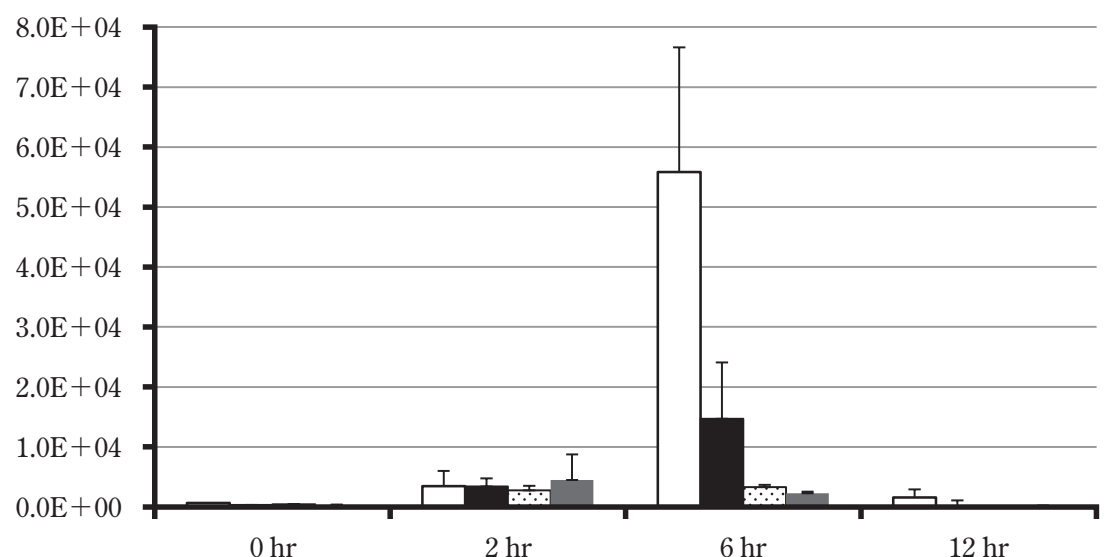

Fig. 3 The time course distributions of the relative fluorescence intensity of the rat brain tumor, the ipsilateral cortical brain and the contralateral cortical brain are shown in arbitrary units after the administration of talaporfin sodium with an excitation wavelength of 405/40 nm and an emission wavelength of $670 \pm 10 \mathrm{~nm}$. The relative fluorescence intensities of the samples were normalized to the relative fluorescence intensities per $1 \mathrm{~g}^{-}$weight of the samples $(n=5)$. 


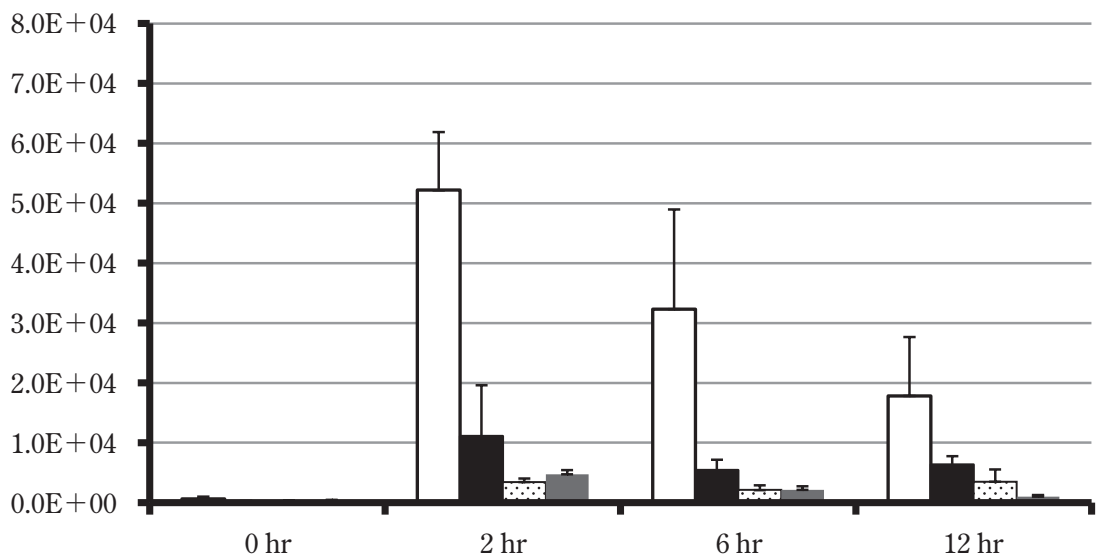

Fig. 4 The time course distributions of the relative fluorescence intensity of the cold-injury-induced vasogenic edema, the ipsilateral cortical brain and the contralateral cortical brain are shown in arbitrary units after the administration of talaporfin sodium with an excitation wavelength of $405 / 40 \mathrm{~nm}$ and an emission wavelength of $670 \pm 10$ $\mathrm{nm}$. The relative fluorescence intensities of the samples were normalized to the relative fluorescence intensities per $1 \mathrm{~g}-$ weight of the samples $(n=5)$.

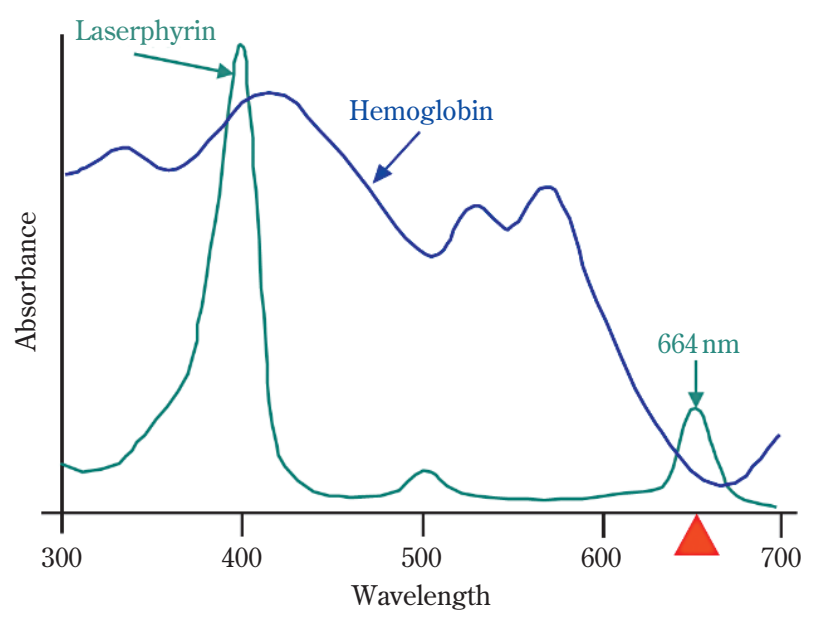

Fig. 5 The absorbance characteristics of talaporfin sodium and hemoglobin. Talaporfin sodium has absorbance peaks at $401 \mathrm{~nm}$ and $664 \mathrm{~nm}$.

この波長の励起光での組織深達度は $5 \mathrm{~mm}$ 程度である ${ }^{2)}$. 国内で悪性脳腫瘍のPDTに使用されている夕ラポル フィンナトリウムも同様の $664 \mathrm{~nm}$ 付近に吸収帯のピー クをもつため, その治療可能深度は同程度と考えられ る. 悪性脳腫瘍に前述のレーザー照射装置を使用して PDT を行う場合の治療可能な深度について詳細なデー 夕は今のところない，肺癌に対する夕ラポルフィンを用

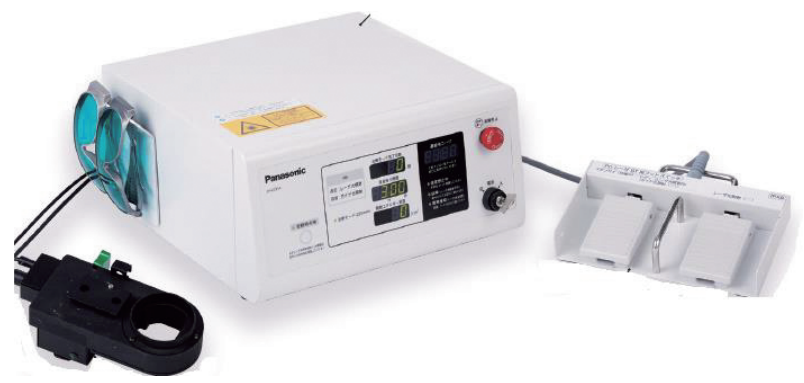

Fig. 6 A 664-nm semiconductor laser source (Panasonic Healthcare), providing a laser beam with a diameter of $1.5 \mathrm{~cm}$, radiation power density of $150 \mathrm{~mW} / \mathrm{cm}^{2}$, and radiation energy density of $27 \mathrm{~J} / \mathrm{cm}^{2}$. In PDT for brain tumors, this laser source is used in combination with a surgical microscope.

いた PDT では $10 \mathrm{~mm}$ 以上の病変に対しても効果が確認 されており ${ }^{16)}$, 実際の PDTの治療効果は物理的なレー ザーの組織深達度を超えて認められるとするデー夕も少 なくない. 前述のごとく, PDT の効果には腫瘍血管への 効果のほか, 免疫系の関与も多く報告されており, TGF, FGF, IL-1, IL-6, PDGF, TNF 等のサイトカインが PDT に伴う細胞障害機構に関して報告されてきている5). 脳 腫瘍の領域においても, 局所のPDTの効果についてより 詳細な検討がなされることが期待される。 


\section{まとめ}

患者の QOL に配慮した低侵襲治療が強く求められる 今日にあって, 脳原発悪性脳腫瘍の外科治療では高い摘 出率達成と神経機能温存の両立が困難な例が少なくない ことから, 腫瘍選択的な特徵をもつPDTは有望な治療手 段である。本治療に用いられる光増感剂である夕ラポル フィンナトリウムは吸収帯が長波長側にあるため高励起 効率が高く, また排泄が早いため光線過敏症等の副作用 が少ない特徵をもつ. 悪性脳腫瘍に対するPDTの第 II 相 試験では，本治療法の安全性と効果が示され，今後の第 III相試験での確認が期待されている。その一方で，照射 部位を広げた場合の安全性, レーザーの深達度と薬剤の 腫瘍選択性といった原理上の制限や免疫系の関与が治療 効果に及ぼす影響, 他の治療法との関係についてはまだ まだ不明な点が多い. 今後, 臨床デー夕の蓄積とともに, こ机ら基礎的な医学デー夕による PDT の適正化や改良 が進むことを期待したい.

著者の COI（conflicts of interest）開示：本論文の発表に関 して開示すべき COI はありません。

\section{文 献}

1) Angell-Petersen E, Spetalen S, Madsen SJ, Sun CH, Peng Q, Carper SW, Sioud M, Hirschberg H : Influence of light fluence rate on the effects of photodynamic therapy in an orthotopic rat glioma model. J Neurosurg 104: 109-117, 2006.

2) Kostron H, Obwegeser A, Jakober R : Photodynamic therapy in neurosurgery : a review. J Photochem Photobiol B $\mathbf{3 6}$ : 157-168, 1996.

3) Matsumura H, Akimoto J, Haraoka J, Aizawa K : Uptake and retention of the photosensitizer mono- $\mathrm{L}$-asparthyl chlorine e6 in experimental malignant glioma. Lasers Med Sci 23 : 237-245, 2008.

4) Miki Y, Akimoto J, Yokoyama S, Homma T, Tsutsumi M, Haraoka J, Hirano K, Beppu M: Photodynamic therapy in combination with talaporfin sodium induces mitochondrial apoptotic cell death accompanied with necrosis in glioma cells. Biol Pharm Bull $36: 215-221,2013$.

5) Mroz P, Hashmi JT, Huang YY, Lange N, Hamblin MR : Stimulation of anti-tumor immunity by photodynamic therapy. Expert Rev Clin Immunol $\quad 7:$ 75-91, 2011.

6) Namatame H, Akimoto J, Matsumura H, Haraoka J, Aizawa $\mathrm{K}$ : Photodynamic therapy of $\mathrm{C} 6$-implanted glioma cells in the rat brain employing second-generation photosensitizer talaporfin sodium. Photodiagnosis Photodyn Ther 5:198-
209, 2008.

7) Pichlmeier U, Bink A, Schackert G, Stummer W ; ALA Glioma Study Group : Resection and survival in glioblastoma multiforme: an RTOG recursive partitioning analysis of ALA study patients. Neuro Oncol 10:1025-1034, 2008.

8) Senft C, Bink A, Franz K, Vatter H, Gasser T, Seifert V: Intraoperative MRI guidance and extent of resection in glioma surgery : a randomised, controlled trial. Lancet Oncol 12: 997-1003, 2011.

9) Seshadri M, Bellnier DA, Vaughan LA, Spernyak JA, Mazurchuk R, Foster TH, Henderson BW : Light delivery over extended time periods enhances the effectiveness of photodynamic therapy. Clin Cancer Res 14:2796-2805, 2008.

10) Shibata $Y$, Matsumura A, Yoshida F, Yamamoto T, Nakai K, Nose T, Sakata I, Nakajima S : Competitive uptake of porphyrin and LDL via the LDL receptor in glioma cell lines: flow cytometric analysis. Cancer Lett 166 : 79-87, 2001.

11) Stummer W, Pichlmeier U, Meinel T, Wiestler OD, Zanella F, Reulen HJ ; ALA-Glioma Study Group : Fluorescenceguided surgery with 5 -aminolevulinic acid for resection of malignant glioma : a randomised controlled multicentre phase III trial. Lancet Oncol $\quad 7: 392-401,2006$.

12) Stupp R, Mason WP, van den Bent MJ, Weller M, Fisher B, Taphoorn MJ, Belanger K, Brandes AA, Marosi C, Bogdahn U, Curschmann J, Janzer RC, Ludwin SK, Gorlia T, Allgeier A, Lacombe D, Cairncross JG, Eisenhauer E, Mirimanoff RO ; European Organisation for Research and Treatment of Cancer Brain Tumor and Radiotherapy Groups ; National Cancer Institute of Canada Clinical Trials Group : Radiotherapy plus concomitant and adjuvant temozolomide for glioblastoma. N Engl J Med 352 : 987-996, 2005.

13) Tsurubuchi $T$, Zaboronok A, Yamamoto $T$, Nakai $K$, Yoshida $F$, Shirakawa M, Matsuda M, Matsumura A: The optimization of fluorescence imaging of brain tumor tissue differentiated from brain edema - in vivo kinetic study of 5-aminolevulinic acid and talaporfin sodium. Photodiagnosis Photodyn Ther 6: 19-27, 2009.

14) Tsutsumi M, Miki Y, Akimoto J, Haraoka J, Aizawa K, Hirano K, Beppu M : Photodynamic therapy with talaporfin sodium induces dose-dependent apoptotic cell death in human glioma cell lines. Photodiagnosis Photodyn Ther $10: 103-110$, 2013.

15) Usuda J, Ichinose $S$, Ishizumi $T$, Hayashi $H$, Ohtani $K$, Maehara S, Ono S, Honda H, Kajiwara N, Uchida O, Tsutsui H, Ohira T, Kato H, Ikeda N : Outcome of photodynamic therapy using NPe6 for bronchogenic carcinomas in central airways $>1.0 \mathrm{~cm}$ in diameter. Clin Cancer Res 16:21982204, 2010.

16) Yamamoto $T$, Matsumura $A$, Shibata $Y$, Fujimori $H$, Nakai $K$, Yoshida F, Nose T, Sakata I, Nakajima S, Miwa N : Manganese-metalloporphyrin (ATN-10) as a tumor-localizing agent: Magnetic resonance imaging and inductively coupled plasma atomic emission spectroscopy study with experimental brain tumors. Neurosurgery $\quad$ 42: 1332-1338, 1998. 
要

悪性脳腫瘍に対する光線力学的療法（PDT）の基礎

$\begin{array}{lllllll}\text { 山本 哲哉 } & \text { 上月 } & \text { 暎浩 } & \text { 鶴淵 } & \text { 隆夫 } & \text { 松田 } & \text { 真秀 } \\ \text { 阿久津博義 } & \text { 石川 } & \text { 栄一 } & \text { 高野 } & \text { 晋吾 } & \text { 松村 } & \text { 明 }\end{array}$

光線力学的療法 (photodynamic therapy：PDT) は, 光増感剤の腫瘍集積性と励起用レーザ一照射 後の光化学反応を利用し, 腫瘍細胞選択的な効果を得ようとする手法である. PDTではレーザー光が 直接腫瘍組織に作用するのではなく, 光エネルギーを吸収して励起状態（一重項状態）に遷移した光 増感剤が基底状態に戻る際のエネルギ一転換により一重項酸素（活性酸素の一種）が発生し，その強 力な酸化作用が腫瘍組織内の光増感剤周囲のごく限られた範囲に短時間作用することで腫揚組織選 択的効果が得られる. この稿では, 原発性悪性脳腫瘍に対するPDTに使用する光増感剤タラポルフィ ンナトリウム，励起用レーザーに焦点をあて，概説した。 